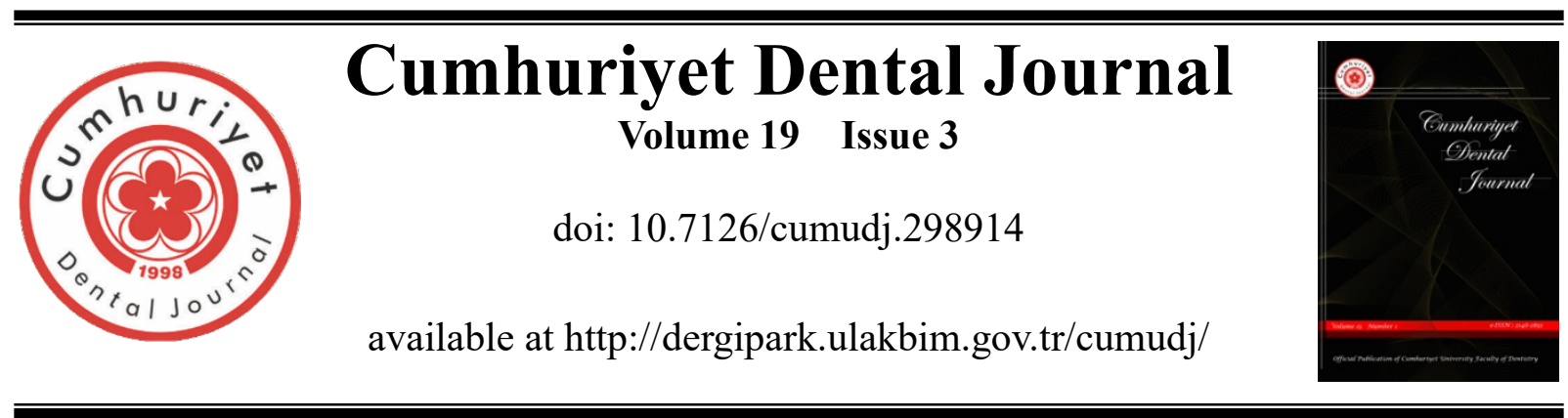

REVIEW ARTICLE

\title{
Indirect Resin Composite Restorations Fabricated With Chairside CAD/CAM Systems
}

\author{
Laden GÜLEÇ, Nuran ULUSOY , Esra CENGIZ², \\ ${ }^{1}$ Department of Restorative Dentistry, Faculty of Dentistry, Near East University, Nicosia, Cyprus \\ ${ }^{2}$ Department of Restorative Dentistry, Faculty of Dentistry, Mersin University, Mersin, Turkey
}

\section{A R T I C L E I N F O}

Article history:

Received 03.03.2016

Accepted 06.10.2016

Keywords:

Chairside CAD/CAM Systems,

Indirect Restoration, $\mathrm{CAD} / \mathrm{CAM}$

Composite Resin, Composite Block
A B S T R A C T

Aesthetics has gained significant importance in restorative dentistry besides the potential requirements including the continuity and integrity of tissue and regaining the function and phonation. The demand for esthetic posterior restorations gave way to the use of resin composites in the posterior region as well as the anterior restorations. However, polymerization shrinkage of resin composites limits this application to only with small sized restorations. In order to eliminate the disadvantage of polymerization shrinkage, various methods have been suggested to improve the properties and application methods of resins with the aim of increasing the longevity and function of restorative materials. For this purpose, computer aided design/computer aided manufacturing (CAD/CAM) systems have been used for the past 10 years to fabricate indirect restorations with resin composites as an alternative material in digital system. This review aims to provide an update on the resin composite materials used with indirect restorations and CAD/CAM systems.

Key words: chairside $\mathrm{CAD} / \mathrm{CAM}$ systems, indirect restoration, $\mathrm{CAD} / \mathrm{CAM}$ composite resin, composite block 


\section{INTRODUCTION}

The main purpose of restorative dentistry is to protect the continuity and integrity of remaining tissue, recover function, phonation and provide aesthetics. Based on all these objectives, it can be claimed that ceramic material holds a special place in dentistry. Advantages of providing the most pleasing aesthetic results, the best color match with natural dentition, compatibility with tissues make the ceramic material unique. ${ }^{1}$

In this context, computer aided design/computer aided manufacturing (CAD/CAM) systems that have gained popularity for the past 10 years use ceramic as the basic material which is continuously being developed. However, ceramic material has many disadvantages such as fragility, requirement of excess time for fabrication and abrasive effect. Additionally, low modulus of elasticity of ceramic material makes it unable to absorb the pressure of mastication. These disadvantages of ceramics have led to increased interest in resin composites that can be repaired intra-orally and have ease of fabrication. ${ }^{2-6}$

The procedure of bonding resin composites to hard dental tissues along with adhesive dentistry is one of the most promising developments in restorative dentistry. The use of dental resin composites in load bearing posterior restorations has gain significant progress by improving the properties of composites for the last 10 years. ${ }^{4,7}$ Excellent mechanical and optical properties were obtained in direct resin composites however the use of the composite material is limited to only with small sized restorations because of its main disadvantage of polymerization shrinkage. ${ }^{8}$
Various clinical methods have been used to eliminate the disadvantage of polymerization shrinkage of resin composites. Application of incremental technique in direct restoration, the use of ceramic inserts with resin composites, control of amount and insertion of the material, appropriate placement of etchant, primer and adhesive in order to improve bonding and also restoration of lost tissue with indirect technique are some of these methods. ${ }^{9,10}$

Indirect restorations that are fabricated extra orally and luted/cemented onto/into the tooth can be categorized as either intracoronal or extracoronal restorations. ${ }^{11}$ Intracoronal restorations are preferred when remaining tooth structure is adequate to retain the restoration and for protecting the tooth against stress formed during mastication. One of the intracoronal restorations, inlay, is the simplest cemented restoration containing occlusal, gingival, proximal lesions and covering at most one tubercule. ${ }^{12}$ Extracoronal restorations are those that cover the outer surface of tooth to create anatomic contours. Full or partial crowns and veneers are examples of extracoronal restorations. ${ }^{11} \mathrm{~A}$ veneer is a layer of toothcolored material that is applied to a tooth to restore localized or generalized defects and intrinsic discolorations ${ }^{9}$ and crown is the restoration that caps clinical tooth length fully or partially. ${ }^{13}$

Those of in-between inlay and full crown restorations termed onlay restorations, cover all over the tubercules of tooth. Additional to the occlusal surface of tooth, restorations that cover the buccal or the lingual surfaces are called overlay. ${ }^{9,11,12}$ Beside these restorations, in 1999, Bindl and Mörmann defined 'endocrown' as an alternative restoration to post-core and crown for the endodontically 
treated teeth that have excessively lost tissue. Endocrowns can be defined as either one-piece ceramic structure bonded by adhesion or onley restorations applied on endodontically treated teeth. ${ }^{14,15}$

The advantages including elimination of requirement of taking conventional impression and preparing temporary restorations, automation of fabrication procedures with increased quality in a short period of time, elimination of hazards of infectious cross-contamination associated with conventional multistage fabrication of indirect restorations and having potential to minimize inaccuracies in technique have made $\mathrm{CAD} / \mathrm{CAM}$ technology an alternative method to the dental laboratory procedures. Due to the capability of usage as laboratory-processed blocks, composites have been able to be used in the fabrication of inlays, onlays, crowns and fixed partial dentures with charside CAD/CAM systems. ${ }^{16-18}$

\section{Chairside systems used in CAD/CAM technology}

Chairside CAD/CAM systems have become a treatment option for the first time with the acquisition of the ceramic inlay in a single session in $1985 .{ }^{19}$ The advantage of these systems are chairside designing and fabricating the restoration in a short period of time and impressing patients with the latest technologic devices. On the other hand, the high cost is an important disadvantage of these systems. In today's technology, there are two chairside systems: CEREC (Sirona Dental Systems,Bensheim, Germany) and E4D Dentist system (D4D Technologies, Richardson, TX, USA). ${ }^{20}$

\section{Cerec CAD/CAM system}

Dr. Mörmann's ${ }^{21}$ in vivo and in vitro studies with pressed and hot polymerized composites set forward the hypothesis that inlays made of tooth-colored materials and inserted adhesively with a luting agent, could solve the polymerization shrinkage problem of direct composite fillings. Based on this idea, ceramic materials were used to get pleasing aesthetic and durable results. The capability of producing ceramic inlays by scanning the preparation directly from the patient and transferring the data to the milling device led up to the foundation of CEREC system. ${ }^{19}$

Ceramic inlay, onlay and laminate veneer restorations were milled at one appointment with CEREC1 that was introduced in 1988. However the required formation of occlusal surface of inlay by manual grinding and limitation of digitizing accuracy of the camera caused the unsatisfactory marginal fit of inlay. ${ }^{18,19}$ With the development of CEREC2 in 1994, the requirement of forming occlusal design manually was left and $30 \%$ increase in marginal integrity was obtained. ${ }^{19,22}$ CEREC3 is the new system which includes; CEREC inLab that was developed in 2004 and CEREC 3 chairside systems. At first CEREC3 created 2dimensional designs and in 2003, new software of 3-dimensional design was developed. ${ }^{19}$

The basic principle of $\mathrm{CAD} / \mathrm{CAM}$ technology is that preparations should reflect the capabilities of CAD software and hardware and CAM milling devices. CEREC System automatically blocks-out the undercuts during scanning. This eliminates the requirement of preparation having a path of draw that allows insertion and removal of restoration without interferences from undercuts in laboratoryfabricated indirect systems. In some cases 
such as preparations with excessive undercuts at the base of tubercules, undercuts should be filled with composite cements to prevent failures during cementation. Some CEREC users prefer to prepare occlusally convergent walls because they accept that CAD software can read the occlusal cavo-surface margins easily by this way. ${ }^{9}$

\section{E4D Dentist System}

E4D Dentist System which was introduced in the early 2008 includes design center (computer/monitor), laser scanner and separate milling unit. ${ }^{23}$ The scanner, termed as IntraOral Digitizer, enables this system to scan the preparation without using reflecting agent, eg.titanium dioxide powder. Compared to the CEREC system, the scanner of E4D has shorter vertical profile preventing patients to open mouth as wide for posterior scans. Actual pictures of the teeth and gingiva before and after tooth preparation and occlusal registration are taken by the ICEverything feature of DentaLogic software of the system. These pictures are then used to create 3D ICE model that let to achieve margin detection simpler. Touch screen monitor of the system let dentist to view the preparation from various angles for accurate results.

The design system of E4D has the ability of auto-detecting and marking finish line on the preparation. The Autogenesis feature of software proposed a restoration, chosen from its anatomical libraries, for the tooth to be restored. ${ }^{23}$ The system is compatible with less number of materials compared with CEREC3 system. These materials are leucite-reinforced ceramics, lithium disilicate blocks, nanoceramics, permanent and temporary composite blocks (Table I). ${ }^{24}$ Studies evaluating the $\mathrm{CAD} / \mathrm{CAM}$ restorations fabricated with different materials and techniques are presented in Table II. ${ }^{25-31}$

Table I: Restorative materials available for chairside CAD/CAM system ${ }^{24}$

\begin{tabular}{|l|l|c|c|}
\hline CATEGORY & $\begin{array}{l}\text { BRAND NAME } \\
\text { (MANUFACTURER) }\end{array}$ & CEREC & E4D \\
\hline \multirow{2}{*}{$\begin{array}{l}\text { Esthetic Ceramics } \\
\text { (Feldspathic) }\end{array}$} & Vitablocs Mark II (Vident) & $\mathrm{X}^{1}$ & \\
\cline { 2 - 4 } & $\begin{array}{l}\text { CEREC Blocs (Sirona Dental } \\
\text { Systems) }\end{array}$ & $\mathrm{X}$ & \\
\hline $\begin{array}{l}\text { Esthetic Ceramics } \\
\text { (Leucite reinforced) }\end{array}$ & $\begin{array}{l}\text { IPS Empress CAD (Ivoclar } \\
\text { Vivadent) }\end{array}$ & $\mathrm{X}$ & $\mathrm{X}$ \\
\hline $\begin{array}{l}\text { High strength ceramic } \\
\text { (Lithium disilicate) }\end{array}$ & $\begin{array}{l}\text { IPS e.max CAD (Ivoclar } \\
\text { Vivadent) }\end{array}$ & $\mathrm{X}$ & $\mathrm{X}$ \\
\hline Nanoceramic & Lava Ultimate (3M ESPE) & $\mathrm{X}$ & $\mathrm{X}$ \\
\hline $\begin{array}{l}\text { Composite Resin } \\
\text { (Final restorations) }\end{array}$ & Paradigm MZlOO (3M ESPE) & $\mathrm{X}$ & $\mathrm{X}$ \\
\hline \multirow{2}{*}{$\begin{array}{l}\text { Composite Resin } \\
\text { (Temporary restorations) }\end{array}$} & Vita CAD-Temp (Vident) & $\mathrm{X}$ & \\
\cline { 2 - 4 } & Telio CAD (Ivoclar Vivadent) & $\mathrm{X}$ & $\mathrm{X}$ \\
\hline
\end{tabular}

${ }^{1} \mathrm{X}$ : Material available for chairside system

Table II. Studies evaluating the CAD/CAM restorations ${ }^{25-31}$

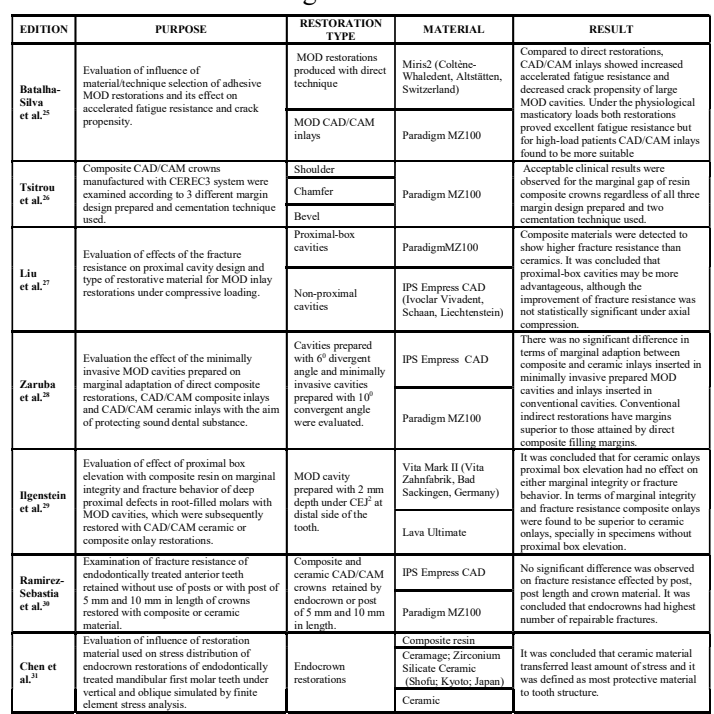

\section{Resin composite blocks used in CAD/CAM technology}

The evolution of direct esthetic materials began with silicate cements developed by Fletcher ${ }^{32}$ in 1878 . Silicates known as anticariogenic materials have several disadvantages such as fragility, acidity and requirement of accurate application. Acrylic resins overcoming these disadvantages of silicates were widely used as unfilled resins in 1940 's. ${ }^{32,33}$

In early 1960's resin composites were developed with advanced mechanical 
properties superior to silicates and acrylic resins. Polymerization of composites was activated chemically at first and then photo-activated by ultraviolet (UV) wavelengths and lastly activated by visible wavelengths. As a result of ongoing studies; durable, wear resistant and esthetic composite materials were developed. Significant progress has been achieved in resin composites particularly as a result of developments in nanotechnology and adhesive dentistry. ${ }^{34}$

In order to improve the biological properties of resin composites and develop their composition; several changes have been applied to organic matrix of composites or the size, shape and distribution ratio of inorganic fillers were changed. Packable, flowable, smart, antibacterial, ormocer, nanofil, lowshrinking/non-shrinking resin composites, giomers, bulk-fill composites, composites used in indirect technique are some of different types of composites named as a result of those changes. ${ }^{35,36}$

Use of composites in chairside CAD/CAM systems can be preferred both temporarily and permanently. Paradigm MZ100 (3M ESPE, Minnesota, USA), is the first commercial composite block introduced in 2000. Blocks are made from Z100 direct restorative resin composite by factory polymerization. ${ }^{6,37,38}$ Factory polymerization resulted in Paradigm MZ100 having superior flexural strength and fracture toughness to those of Z100.,39 Paradigm MZ100 is a radio opaque composite block material which contains $85 \mathrm{wt} \%, 0.6$ micrometer sized ultrafine zirconia-silica ceramic particles that reinforce a highly cross-linked polymeric matrix. These blocks are made in two cylindrical sizes (3M size10, 3M size 14$)$, in six shades (A1,A2,A3,A3,5, B3, Enamel). ${ }^{37}$ Block HC (Shofu; Kyoto,
Japan) is a composite block composed of 61 wt.\% silica powder, zirconium silica and micro-clustered silica particules ${ }^{40}$ and Gradia Block (GC; Tokyo, Japan) is an another composite block including 76 wt.\% silica, F-Al-silicate glass and prepolymerized filler. ${ }^{41}$

Chairside CAD/CAM systems may not be adequate to treat all clinical situations. CAD/CAM temporary blocks have been introduced for chairside fabrication of long-term temporary restorations in order to complete the laboratory fabrication process. TelioCAD and VITA-CAD Temp are temporary blocks used for long-terms temporary crowns and fixed partial dentures. ${ }^{24}$ TelioCAD is a block made of 99,5 wt.\% polymethyl methacrylate (PMMA) and can be milled both in the laboratory (labside) and in office (chairside). The block is used to mill both full-contour single-tooth and multiple-unit temporary restorations using $\mathrm{CAD} / \mathrm{CAM}$ technology and is a part of Telio system including desensitizer, self-curing composite and cement. It is in two sizes; $40 \mathrm{~mm}$ and $55 \mathrm{~mm}$ and in six shades. ${ }^{24,42,43}$ Another temporary block, VITA CADTemp block, is fiber-free, homogeneous, high-molecular and cross-linked acrylate polymer with microfiller. Blocks are used for the fabrication of long-term temporary full and partial crowns and fixed partial dentures up to two pontics. There are two types of blocks which are monoColor and multiColor. MultiColor blocks have four different chroma layers that provides esthetic restorations. ${ }^{44,45}$

Integration of nanotechnology and ceramics has led to the improvement of a unique $\mathrm{CAD} / \mathrm{CAM}$ material; nanoceramic, aimed to offer the ease of handling of a composite material with the superiority of surface gloss and finish retention of ceramic. The firstly developed, Lava 
Ultimate (3M ESPE; Minnesota, USA), contains three different ceramic particles all embedded in a highly cross-linked polymer matrix (silicate particle of $20 \mathrm{~nm}$, zirconia particles of $4 \mathrm{~nm}$ to $11 \mathrm{~nm}$, agglomerated nano particles of $20 \mathrm{~nm}$ silica and $4-11 \mathrm{~nm}$ zirconia). The material that has 80 wt. $\%$ zirconia and silica nanoparticles and nanoclusters is available for both CEREC and E4D Systems and has eight different shades. ${ }^{24,40}$

A newly developed hybrid material, ENAMIC (VITA Zahnfabrik, Bad Säckingen, Germany) includes proven properties of composite and ceramic materials. Inorganic ceramic part of this block is 86 wt. $\%$ and organic polymer matrix is 14 wt. $\%$ and pores in the structure-sintered ceramic matrix are filled with a polymer material. ${ }^{46}$ Another material that combines best characteristics of high strength ceramic and composite is CERASMART (GC, Alsip, USA) which has flexible nanoceramic matrix. It is composed of 71 wt. \% silica $(20 \mathrm{~nm})$ and barium glass $(300 \mathrm{~nm})$ nanoparticles ${ }^{41,47}$

Studies evaluating physical and mechanical properties of CAD/CAM blocks are shown in Table III. ${ }^{41,48-53}$
Table III. Studies Evaluating Physical and Mechanical Properties of Materials $\mathrm{s}^{41,47-53}$

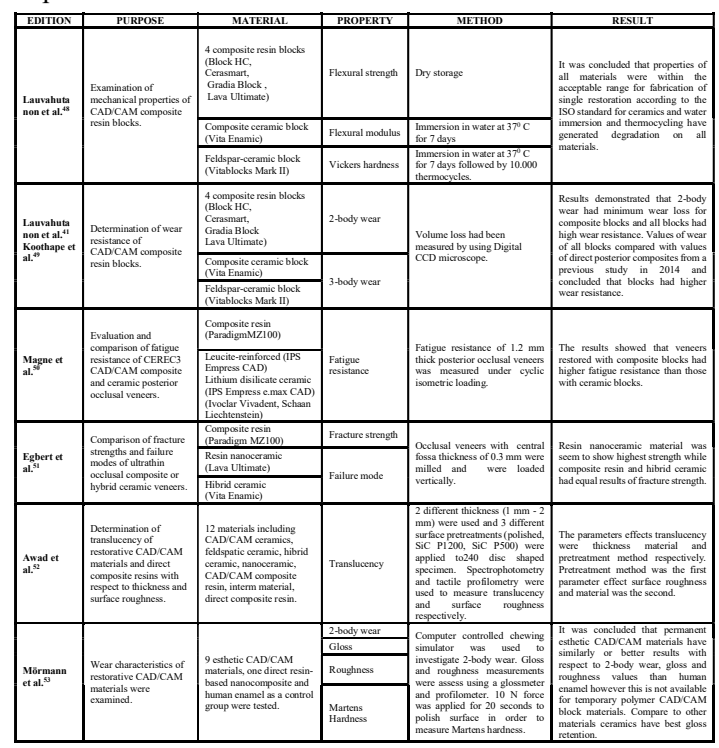

\section{CONCLUSION}

Indirect composite restorations fabricated with $\mathrm{CAD} / \mathrm{CAM}$ technology have been presented as an alternative to the ceramic restorations with improved physical, mechanical and esthetic properties. While available chairside CAD/CAM systems have several advantages, there is also wide range of limitations of them. Studies investigating mechanical properties and physical changes that occur after heat treatment and compliance with natural dentition of materials used in CAD/CAM systems are still not enough. In the future, additional to the studies aimed to eliminate these deficiencies, in vitro studies examining production techniques and production accuracy of systems and in vivo studies following the success of restorations fabricated with these systems should be planned.

\section{REFERENCES}

1. Ural Ç. Diş hekimliği pratiğinde tamamı seramik ve CAD/CAM uygulamaları. Dirim Tip Gazetesi 2011; 86(1): 27-38. 
2. Giardano R. Materials for chairside CAD/CAM-produced restorations. J Am Dent Assoc 2006; 137(9): 14-21.

3. Karaarslan EŞ, Ertaş E. İndirekt posterior kompozit rezin restorasyonlar. Ondokuz Mayıs Univ Dis Hekim Fak Derg 2010; 10(3): 116-24.

4. Nguyen JF, Migonney V, Ruse ND, Sadoun M. Resin composite blocks via high-pressure high-temperature polymerization. Dent Mater 2012; 28 : 529-34.

5. Rocca GT, Bonnafous F, Rizcalla N, Krejci I. A technique to improve the esthetic aspect of CAD/CAM composite resin restoration. J Prosthet Dent 2010; 104: 273-75.

6. Ruse ND, Sadoun MJ. Resin composite blocks for dental CAD/CAM applications. J Dent Res 2014; 93(12): 1232-4.

7. Ferracane JL. Resin composite-state of art. Dent Mater 2011; 27: 29-38.

8. Terry DA, Touati B. Clinical considerations for aesthetic laboratoryfabricated inlay/onlay restorations: a review. PPAD 2001; 13(1):51-8.

9. Roberson TM, Heymann HO, Swift EJ. Sturdevant's Art and Science of Operative Dentistry. 5th ed. Ankara: Güneş Tip Kitabevleri 2011.p: 504,505, 611, 614, 652.

10. Arıkan S. Posterior kompozit restorasyonlar. Cumhuriyet Dent $\mathrm{J}$ 2005; 8(1):1-8.

11. Qualtrough AJE, Satterthwaite JD, Morrow LA, Brunton PA. Principles of operative dentistry, 1st ed. Oxford: Blackwell Publishing, 2005, p: 107,108.

12. Köksal T, Dikbaş I, Çapa N. Seramik inley ve onley restorasyonlar. Journal of Istanbul University Faculty of Dentistry 2007; 41:71-82.
13. Shillingburg HT, Hobo S, Whitsett LD, Jacobi R ve Brackett SE. Sabit Protezin Temelleri, 3rd ed., İstanbul: Quintessence Yayıncılık, 2010. p.1.

14. Fages M, Bennasar B. The endocrown: different type of all-ceramic reconstruction for molars. J Can Dent Assoc 2013; 79: d140.

15. Dzieciatkowska M. Reconstruction of a tooth with composite endocrown following root canal treatment. Endodontic Practice US 2015. Acces: 20.11.2015, http://www.kerrdental.eu/catalogfiles/clinicalarticles/0/107/files/Reconstruction-of-atooth with-composit-endocrown.pdf

16. Feurstein P. Can technology help dentists deliver better patient care? J Am Dent Assoc 2004; 135: 11-6

17. Liu PR. A panorama of dental $\mathrm{CAD} / \mathrm{CAM}$ restorative systems. Compend Contin Educ Dent 2005; 26(7): 507-13.

18. Miyazaki T, Hotta Y, Kunii J, Kuriyama S, Tamaki YA. Review of dental CAD/CAM: current status and future perspectives from 20 years of experience. Dent Mater 2009; 28(1): 4456.

19. Mörmann WH. The evolution of the CEREC system. J Am Dent Assoc 2006; 137(9):7-13.

20. Çelik G, Üşümez A, Sarı T. Bilgisayar destekli diş hekimliği ve güncel CAD/CAM sistemleri. Cumhuriyet Dent J 2013;16(1): 74-82.

21. Mörmann WH. The origin of the CEREC method: a personal review of the first 5 years. Int $\mathrm{J}$ Comput Dent 2004; 7(1):11-24.

22. Mörmann WH, Schug J. Grinding precision and accuracy of fit of 
CEREC2 CAD/CAM inlays. J Am Dent Assoc 1997; 128(1): 47-53.

23. Birnbaum NS, Aaronson HB. Dental impressions using 3D digital scanners: virtual becomes reality. Compend Contin Educ Dent 2008; 29(8):494, 496, 498-505.

24. Fasbinder DJ. Chairside CAD/CAM: An overview of restorative material options. Compend Contin Educ Dent 2012; 33(1):50-8.

25. Batalha-Silva S, Caldeira de Andrada MA, Maia HP, Magne P. Fatigue resistance and crack propensity of large MOD composite resin restorations: direct versus $\mathrm{CAD} / \mathrm{CAM}$ inlays. Dent Mater 2013; 29: 324-31.

26. Tsitrou EA, Northeast SE, Noort R. Evaluation of the marginal fit of three margin designs of resin composite crowns using CAD/CAM. J Dent 2007; 35: 68-73.

27. Liu X, Fok A, Li H. Influence of restorative material and proximal cavity design on the fracture resistance of MOD inlay restoration. Dent Mater 2014; 30: 327-33.

28. Zaruba $M$, Kasper $R$, Kazama $R$, Wegehaupt FJ, Ender A, Attin T, Mehl A. Marginal adaptation of ceramic and composite inlays in minimally invasive MOD cavities. Clin Oral Invest 2014; 18: 579-87.

29. Ilgenstein I, Zitzmann NU, Bühler J, Wegehaupt FJ, Attin T, Weiger R. Influence of proximal box evaluation on the marginal quality and fracture behavior of root-filled molars with CAD/CAM ceramic or composite onlays. Clin Oral Invest 2015; 19: 102128.

30. Ramirez-Sebastia A, Bortolotto $T$, Cattani-Lorente M, Giner L, Roig M, Krejci I. Adhesive restoration of anterior endodontically treated teeth: influence of post length on fracture strength. Clin Oral Invest 2014; 18: 545-54.

31. Chen B, Ma Y, Wu K, Chen H, Li L, Liang L, Jun L, Zhi C. Influence of various materials on biomechanical behavior of endocrown-restored, endodontically-treated mandibular first molar: a 3D-finite element analysis. Journal of Wuhan University of Technology- Mater Sci Ed 2015; 30(3): 643-48.

32. Dayangaç GB. Kompozit Restorasyonlar, 2nd ed. İstanbul: Quintessence Yayınc1lık 2011,p:1.

33. McCabe JF, Walls AWG. Applied Dental Materials, 9th ed, Oxford: Blackwell Publishing 2008, p.195.

34. Sakaguchi RL, Powers JM. Craig's Restorative Dental Materials, 13th ed, Philadelphia: Mosby 2012, p.162.

35. Gökçe K, Özel E. Kompozit restorasyonlarda son gelişmeler. Atatürk Üniv. Diş Hek .Fak Derg 2005; 15(3):52-60.

36. Türkün LŞ. Dünden Bugüne Kompozit Rezinler. (p. 15-22). Access: 21.11.2015, http://www.slideshare.net/sebnemturkun /kompozit-rezinler-gmag-51931136

37. 3M paradigm MZ100 block technical product profile. (2000). (p. 2-25). Access: 16.10.2015, http://multimedia.3m.com/mws/media/7 75960/paradigmtm-mz100-

38. Fasbinder DJ. Materials for chairside $\mathrm{CAD} / \mathrm{CAM}$ restorations. Compend Contin Educ Dent 2010; 31(9): 702-9.

39. Nguyen JF, Migonenney V, Ruse ND, Sadoun M. Properties of experimental urethane dimethacrylate-based dental resin composite block obtained via thermo-polymerization under high 
pressure. Dent Mater 2013; 29(5): 53541.

40. Stawarczyk B, Liebermann A, Eichberger M, Güth JF. Evaluation of mechanical and optical behaviour of current esthetic dental restorative CAD/CAM composites. J Mech Behav Biomed Mater 2016; 55: 1-11

41. Lauvahutanon S, Takahashi H, Oki M, Arksornnukit M, Kanehira M, Finger WJ. In vitro evaluation of the wear resistance of composite resin blocks for CAD/CAM. Dent Mater 2015; 34(4):495-502.

42. Telio. The compatible system solution for temporary restorations. (2014). (p.2$8)$.

Access:

08.11.2015,http://www.ivoclarvivadent. com/zooluwebsite/media/document/282 79/Telio+Chairside+System.

43. Wanner M. Scientific documentation of Telio CAD. (2010). (p. 2-11). Access: 19.10.2015, http://www.ivoclarvivadent.us/enus/products/chairside-cad_camblocks/telio-cad

44. VITA CAD-Temp Disc (p. 1-2). Access: 16.10.2015, http://vitanorthamerica.com/wp content/uploads/2008/12/VITA-1806Nr.-1806-VITA-CAD-Temp-DISC-enScreen.pdf

45. Beuer F, Schweiger J, Edelhoff D. Digital Dentistry: an overview of recent developments for CAD/CAM generated restorations. Br Dent J 2008; 204(9): 505-11.

46. Sannino G, Germano F, Arcuri L, Bigelli E, Arcuri C, Barlattani A. CEREC CAD/CAM chairside system. JOI 2014; 7(3): 57-70.

47. Cerasmart: Force absorbing flexible nanoceramic CAD/CAM block. Access:
15.1.2016, http://www.gcamerica.com/lab/products /CERASMART/GCA_CERASMART Bro-iPad.pdf

48. Lauvahutanon S, Takahashi $H$, Shiozawa M, Iwasaki N, Asakawa Y,Oki M, Finger WJ, Arksornnukit M. Mechanical properties of composite resin blocks for CAD/CAM. Dent Mater 2014; 33(5):705-10.

49. Koottathape N, Takahashi H, Iwasaki N, Kanehira, Finger WJ. Quantitive wear and wear damage analysis of composite resins in vitro. $\mathrm{J}$ Mech Behav Biomed Mater 2014; 29: 508-16.

50. Magne $P$, Schlichting LH, Maia $P$, Baratieri $L N$. In vitro fatigue resistance of $\mathrm{CAD} / \mathrm{CAM}$ composite resin and ceramic posterior occlusal veneers. J Prosthet Dent 2010; 104:149-57.

51. Egbert JS, Johnson AC, Tantbirojn D, Versluis A. Fracture strength of ultrathin occlusal veneer restorations made from CAD/CAM composite or hybrid ceramic materials. Oral Sci Int 2015; 12: $53-8$.

52. Awad D, Stawarczyk B, Liebermann A, Ilie N. Translucency of esthetic dental restorative $\mathrm{CAD} / \mathrm{CAM}$ materials and composite resins with respect to thickness and surface roughness. J Prosthet Dent 2015; 113:534-40.

53. Mörmann WH, Stawarczyk B, Ender A, Sener B, Attin T, Mehl A. Wear characteristics of current aesthetic dental restorative $\mathrm{CAD} / \mathrm{CAM}$ materials: Twobody wear, gloss retention, roughness and Martens hardness. J Mech Behav Biomed Mater 2013; 20: 113-25. 